\title{
Cytotoxic activity of the sub-fraction 2125 from Vernonia scorpioides against Sarcoma 180 tumor cells in mice
}

\author{
Maria Regina O. Kreuger, ${ }^{*, 1,2,3}$ Maique W. Biavatti, ${ }^{1}$ Eduardo S. Pacheco, ${ }^{2}$ Reinaldo R. A. \\ Júnior, ${ }^{2}$ Luise Zozula Blind, ${ }^{1}$ Rômulo D’Avila Pedrini ${ }^{3}$
}

\author{
${ }^{1}$ Núcleo de Investigações Químico-Farmacêuticas (NIQFAR), Curso de Farmácia, Universidade do Vale do Itajaí, \\ Rua Uruguai 458, 88303-202 Itajai-SC, Brazil, \\ ${ }^{2}$ Curso de Medicina, Universidade do Vale do Itajaí, Rua Uruguai 458, 88303-202 Itajai-SC, Brazil, \\ ${ }^{3}$ Curso de Odontologia, Universidade do Vale do Itajai, Rua Uruguai 458, 88303-202 Itajai-SC, Brazil,
}

\begin{abstract}
RESUMO: “Ação citotóxica da sub-fração 2125 de Vernonia scorpioides contra células do Sarcoma 180 em camundongos”. O efeito da sub-fração SF-2125 obtida do extrato das folhas de Vernonia scorpioides foi investigado em camundongos portadores do tumor ascítico Sarcoma 180 (S180). Os animais foram tratados com SF-2125 na concentração de $5 \mathrm{mg} / \mathrm{kg}$, administrada por vias intraperitoneal e intravenosa durante o desenvolvimento do tumor. O tratamento com SF-2125 $5 \mathrm{mg} / \mathrm{kg}$ i.p. aumentou o tempo de vida dos animais, manteve seu peso corporal e o tumor na forma ascítica não teve desenvolvimento. $\mathrm{O}$ tratamento intravenoso não reduziu o volume do tumor.
\end{abstract}

Unitermos: Sarcoma 180, sub- fração 2125, Vernonia scorpioides.

\begin{abstract}
The effect of the selected sub-fraction SF-2125 of the Vernonia scorpioides leaf extract on Sarcoma 180 (S180) ascitic tumor-bearing mice was investigated. The animals were treated with SF-2125 at a concentration of $5 \mathrm{mg} / \mathrm{kg}$, administered intraperitoneally and intravenous during the development of the tumor. Treatment with SF-2125 $5 \mathrm{mg} / \mathrm{kg}$ i.p. increased the lifespan of the animals, maintained their body and the ascitic tumor showed no development. Intravenous treatment did not reduce the tumor volume.
\end{abstract}

Keywords: Sarcoma 180, sub- fraction 2125, Vernonia scorpioides.

\section{INTRODUCTION}

Vernonia scorpioides (Lam.) Pers., Asteraceae, popularly known as Piracá, Enxuga or Erva-de-SãoSimão in Portuguese, is very common in Brazil, and usually grows in poor and deforested neotropical soils (Cabrera,1980). The genus Vernonia produces characteristic compounds such as sesquiterpene lactones, with several reported biological activities, such as fungistatic (Krishna Kumari et al., 2003), and cytotoxic activities (Kuo et al., 2003). Previous studies of the Vernonia scorpioides crude extract have shown moderate bactericide activity and mild wound healing effects (Leite et al., 2002; Biavatti et al., 2007). We observed a pro-inflammatory profile of the crude extract from Vernonia scorpioides in healthy skin tissue (Dalazen et al., 2005). In our previous work we investigated the effect of the dichloromethane fraction (DCM) from the crude extract on Ehrlich ascitic and solid tumors in mice. Dichloromethane fraction showed high cytotoxicity against tumor cells, especially when applied in loco to the tumor development (Pagno et al., 2006). This promising antitumoral result obtained with the DCM fraction led us to partition it, in order to obtain fractions of increasing polarity and the ethyl acetate sub-fraction (SF 2125) showed the highest cytotoxicity against Sarcoma 180 ascitic tumor cells when applied in loco to the tumor development.

\section{MATERIAL AND METHODS}

\section{Extract, fractions and sample preparation}

Flowers and fresh leaves $(600 \mathrm{~g})$ of the plant were macerated with $6,000 \mathrm{~mL}$ of ethanol for seven days, in the absence of light, and the extract obtained was reduced to $1 / 6$ of the initial volume, under vacuum, using a Rotary Evaporator. To the crude extract 
obtained, water ( $600 \mathrm{~mL}$ ) was added and the extract was submitted to liquid-liquid fractioning using solvents with increasing polarities. The respective fractions obtained were nominated: (HEX, $1.16 \mathrm{~g}$ ), dichloromethane (DCM, $420 \mathrm{mg}$ ), ethyl acetate (EA, $560 \mathrm{mg}$ ) and water. After screening with all fractions, DCM showed high activity against the tumor cells (no tumor development was observed) and was selected for chromatographic fractionation using silica flash $(0.04-0.063 \mathrm{~mm})$ and increasing gradient of hexane-ethyl acetate as eluent. The biomonitoring of expressive fractions obtained was done by dissolving aliquots in saline solution using up to $2 \%$ of Tween 80 with the aid of an ultrasonic bath (10 $\mathrm{min}$ ) in the following concentrations: 200, 100, 50, 30, 15 and $5 \mathrm{mg} / \mathrm{kg}$ in a maximum final volume of $200 \mu \mathrm{L}$, and were frozen until the day of application.

The DCM fraction and the subsequent active sub fraction (SF 2125) were characterized by IR and NMR spectroscopy, and its spectra were recorded in a Bomem FT-IR (from UNIVALI) and in a BRUKER AVANCE 400 (NMR laboratory from Chemistry Department -UFSCar/SP), respectively.

\section{Animals}

Adult male inbred Swiss mice (8 weeks), weighing 20-30 g, maintained under standard environmental conditions, were used. They were fed with a standard diet and water ad libitum. The animals were used after an acclimatization period of 7 days, and the experiments were conducted in accordance with the Univali Ethics Committee.

The S180 tumor cells were maintained in the ascitic form by passages in syngenic Swiss mice weekly, with transplantation of $5 \times 10^{6}$ tumor cells intraperitoneally (ip.). The ascitic fluid was removed by opening the belly and collecting all the fluid using a sterile syringe. Ascitic tumor cell counts were carried out in a Neubauer hemocitometer, using the Trypan blue dye exclusion method. The animals used for the experiment received i.p. $200 \mu \mathrm{l}$ of a suspension containing $5 \times 10^{6}$ tumor cells, according to a previous study (Matsuzaki et al., 2003).

\section{Treatment of animals}

After intraperitoneally implanting the tumor cells, three groups of mice (8 mice per group) were treated with $5 \mathrm{mg} / \mathrm{kg}$, intraperitoneal (i.p.) or intravenous (i.v.\} in a vein from the tail, the positive control group received 5-fluoro-uracil (5-FU) in saline solution 0.9\% (20 mg/kg i.p. or i.v.) (Christina et al., 2003) and the negative control group received saline solution $0.9 \%$ in the same via and final volume. The body weights of the mice were measured daily, until their death. The only animals to survive (those which received $5 \mathrm{mg} / \mathrm{kg}$ of SF-2125) were sacrificed 25 days after the start of the treatment.

\section{Effect of SF-2125 on the ascitic tumor}

Six groups of eight mice were used. Treatment was begun immediately after inoculation of the tumor cells. Group 1 received $5 \mathrm{mg} / \mathrm{kg}$ of SF-2125 i.p., group 2 received 5-fluoro-uracil (5-FU) $20 \mathrm{mg} / \mathrm{kg}$ i.p. and group 3 received saline $0.9 \%$ i.p. Group 4 received $5 \mathrm{mg} / \mathrm{kg}$ of SF-2125 i.v., group 5 received 5 -fluoro-uracil (5-FU) $20 \mathrm{mg} / \mathrm{kg}$ i.v. and group 6 received saline $0.9 \%$ i.v. After 7 days, the mice were sacrificed and all the ascitic fluid was harvested for volume measurement and ascitic tumor cell count using the Trypan blue dye exclusion method.

\section{Determination of the cytotoxicity of SF-2125 on S180 cells in vitro}

$5 \times 10^{6}$ S180 ascitic tumor cells were pretreated in vitro with saline solution (group 1), 5-FU 20 $\mathrm{mg} / \mathrm{L}$ (group 2) or $5 \mathrm{mg} / \mathrm{L}$ of SF-2125 of V. scorpioides (group 3) for 15 minutes in vitro, and injected into the abdominal cavities of 8 mice. After 7 days, the mice were sacrificed and all the ascitic fluid was harvested for volume measurement and ascitic tumor cell count using the Trypan blue dye exclusion method.

\section{Statistical analysis}

The results were expressed as mean \pm standard deviation. The statistical evaluation was carried out using the Dunnett's test and the F Test. The significance level was established at $\mathrm{p} \leq 0.05 \%$.

\section{RESULTS}

Evaluation of the lifespan and body weight of the animals after intraperitoneal and intravenous treatment with SF-2125

Animals inoculated with $5 \times 10^{6}$ S180 cells i.p. were divided into 6 treated groups $(n=8)$, receiving 5 $\mathrm{mg} / \mathrm{kg}$, the negative controls groups (saline solution ) and the positive controls groups were treated with 5 -fluoro-uracil (5-FU) $20 \mathrm{mg} / \mathrm{kg}$. Mice were treated by intraperitoneal or intravenous via. Mice treated with the $5 \mathrm{mg} / \mathrm{kg}$ of SF-2125 i.p. survived all the treatment and were sacrificed after 25 days (Figure 1).

Treatment with a dose of $5 \mathrm{mg} / \mathrm{kg}$ SF-2125 determined less loss of body weight during the 10-day period (Figure 2).

\section{Antitumor activity of SF-2125 immediately implantation of ascitic tumor cells}

Figures 3 and 4 show the effect of intraperitoneal and intravenous administration of the SF-2125 against tumor cells, when treatment was initiated immediately 
after the implantation of the tumor cells. The result observed was the suppression of $100 \%$ of the tumor cells and ascitic volume, when mice were treated with the sub-fraction by i.p. immediately after the inoculation of S180 cells. Intravenous treatment with SF-2125 did not reduce the tumor volume and number of tumor cells. The results found were similar to the saline treatment. Mice treated with 5-FU by both via did not develop ascitic tumor.

\section{In vitro cytotoxicity}

Figures 5 and 6 indicate that when the S180 tumor cells were pre-treated in vitro with $5 \mathrm{mg} / \mathrm{kg}$ SF-2125 or $20 \mathrm{mg} / \mathrm{kg}$ of 5 -FU for 15 minutes and injected into the abdominal cavity, there was no tumor development.

\section{DISCUSSION}

Many substances for anticancer chemotherapies in use today are plant-derived products, such as vincristine, vimblastine, taxol. We recently showed that when the tumor was developed in the ascitic form, daily intraperitoneal inoculation of DCM fraction from Vernonia scorpioides extract led to an increase in peritoneal leukocytes, and the tumor did not grow, increasing the animals' lifespan and maintaining the body weight during the 30 days of treatment. (Pagno et al., 2006). These results show that besides tumoricide effects, DCM fraction also has inflammatory activity. Our previous results confirmed the toxic properties of DCM fraction, which is characterized as a darkgreen semi-solid material rich in pigments, and was characterized by infrared spectroscopy, showing strong absorption at ca $1725 \mathrm{~cm}^{-1}$ (Figure 7), characteristic of the presence of lactones. The ${ }^{13} \mathrm{C}$ NMR spectra (Figure 8) of the SF 2125 shown presence of acetyl and carbonyl radicals, due to the presence of intense signs at 168-170 and $20 \mathrm{ppm}$. Also some hydroxyl/methoxyl derivatives can be expected (68 and 55 ppm, intense peaks) and double bonds (124-128 ppm). Because of the strong presence of sesquiterpene lactones in this fraction, it was selected to perform this study. Acetylated sesquiterpene lactones are commonly found in Vernonia species (Kuo et al., 2003). The subfraction used in this experiment, SF2125, was obtained from DCM fraction, confirms the toxic properties of these compounds. In this study, we showed that the SF 2125, obtained from the chromatographic fractionation of the DCM fraction of $V$. scorpioides had the same activity showed by Pagno et al., 2006. Treatment with SF-2125 totally inhibited the development of the ascetic tumor S180 when in direct contact with tumor cells, as also demonstrated through in vitro intraperitoneal administration, in loco, to the ascitic tumor development. SF-2125 (5 $\mathrm{mg} / \mathrm{kg}$ ) inoculation increased the animals' lifespan

\section{Sunvival proportions}

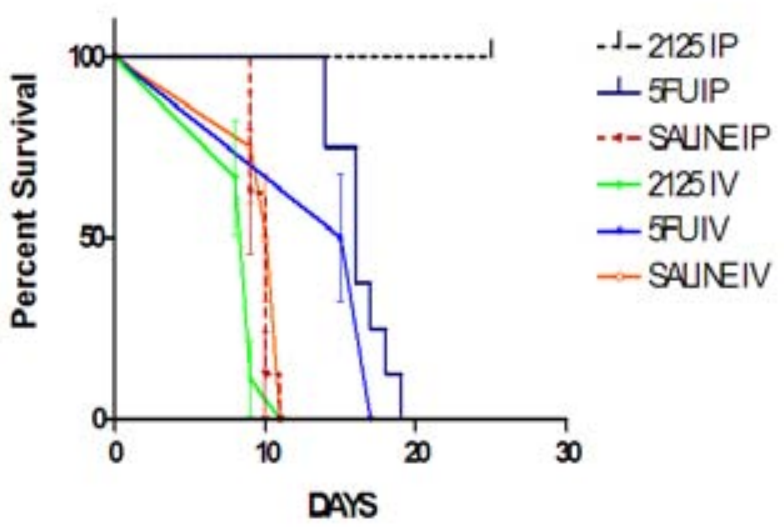

Figure 1. Kaplan-Meier survival curve of mice treated i.p. or i.v. with saline, $5-\mathrm{FU}$ or $5 \mathrm{mg} / \mathrm{kg}$ of SF-2125. Animals treated i.p. with the sub-fraction presented high lifespan (log-rank test $\mathrm{P}<0.0001)$.

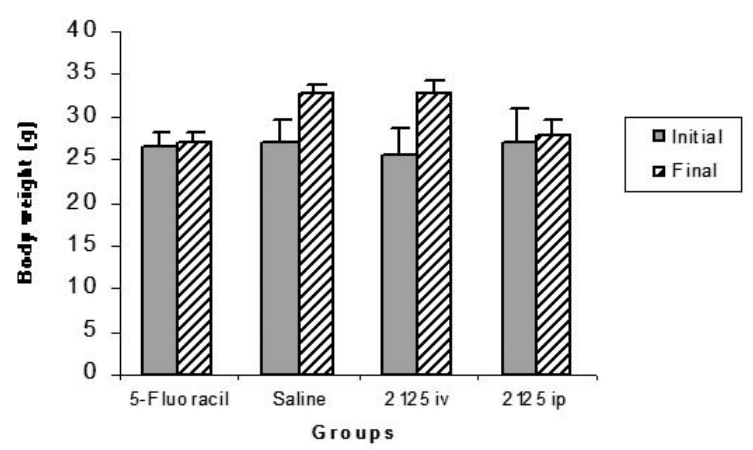

Figure 2. Initial body weight (first day of treatment) and final body weight (after 10 days) mice treated with saline (i.p.), 5-FU (i.p.) or $5 \mathrm{mg} / \mathrm{kg}$ of SF-2125 i.p. and i.v. Mice treated with 5-FU and SF-2125 i.p. had low difference between initial and final body weight. SF-2125 i.v. and saline $0.9 \%$ treatment did not reduce tumor volume increasing the mice body weight. The difference of initial and final body weight was significant between the mice treated by i.v. and mice treated with saline, as determined by analysis of variance using F Test $(p \leq 0.05)$.

and maintained the body weight during 30 days of treatment. When applied immediately after inoculation of the tumor cells in vivo, it totally abolished the tumor development, and when treatment began 3 days after the tumor challenge, the tumor development was decreased, sustaining a probable antineoplastic activity. The fact of the intravenous treatment did not reduce the ascitic tumor volume, suggest that some enzymatic route could be deactivating the systemic via, according with previous results, where mice treated by oral via with DCM fraction of V. scorpioides did not reduce Ehrlich's ascitic or solid tumor (Pagno et al., 2006). Among the Vernonia species, some cytotoxicity has been described for isolated sesquiterpene lactones from $V$. cinerea (Kuo et al., 2003) and V. lasiopus (Koul et al., 2003). Vernonia 


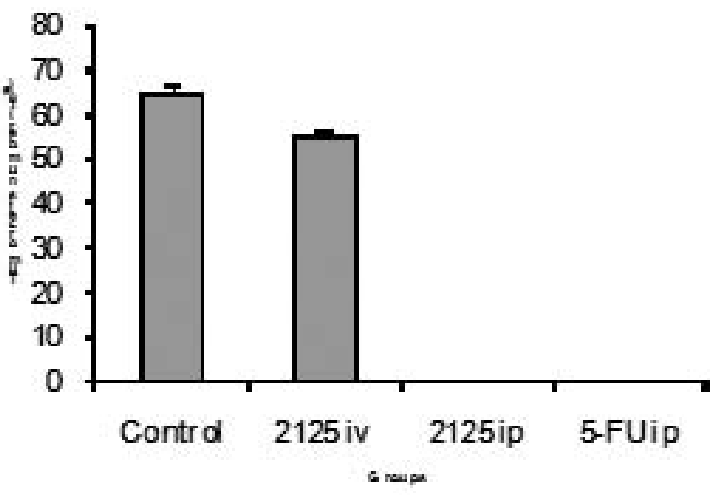

Figure 3

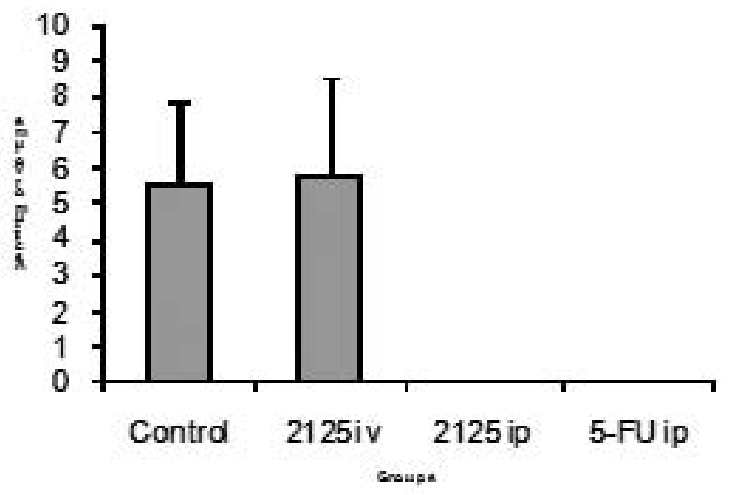

Figure 4

The relative number of tumor cells (Figure 3 ) and total ascitic tumor volume (Figure 4 \} following intravenous and intraperitoneal administration, once a day, with SF-2125 of V. scorpioides, the standard reference drug 5-fluoro-uracil, and saline $0.9 \%$ control, immediately after inoculation of the $5 \times 10^{6}$ EAT cells and continuing for seven consecutive days. No significant difference in cell number and tumor volume between the mice treated by i.v. and the control group was noted, as determined by analysis of variance using F Test ( $\mathrm{p} \leq 0.05)$.

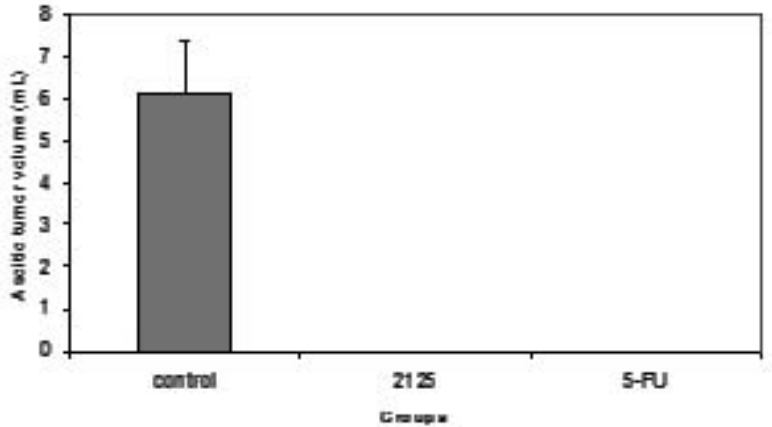

Figure 5

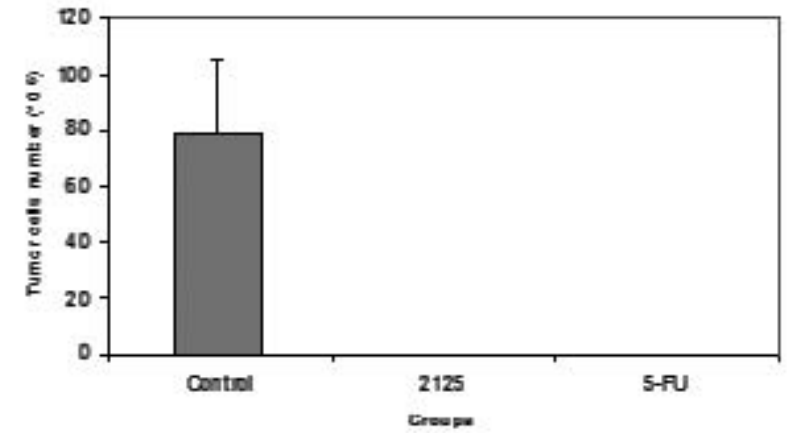

Figure 6

Total ascitic tumor volume (Figure 5) and viable tumor cells $\left(5 \times 10^{6}\right)$ (Figure 6) from the peritoneal cavity of the mice in the in vitro tumor neutralization assay. Tumor cells were pre-treated in vitro with saline, 5-FU or SF-2125 of $V$. scorpioides for 15 minutes and after were inoculated into the peritoneal cavity of the mice Control: Tumor cells pre-treated with saline $0.9 \%$. The total ascitic volume of the animals was harvested after 7 days. The mean values obtained $(n=8)$ are presented.

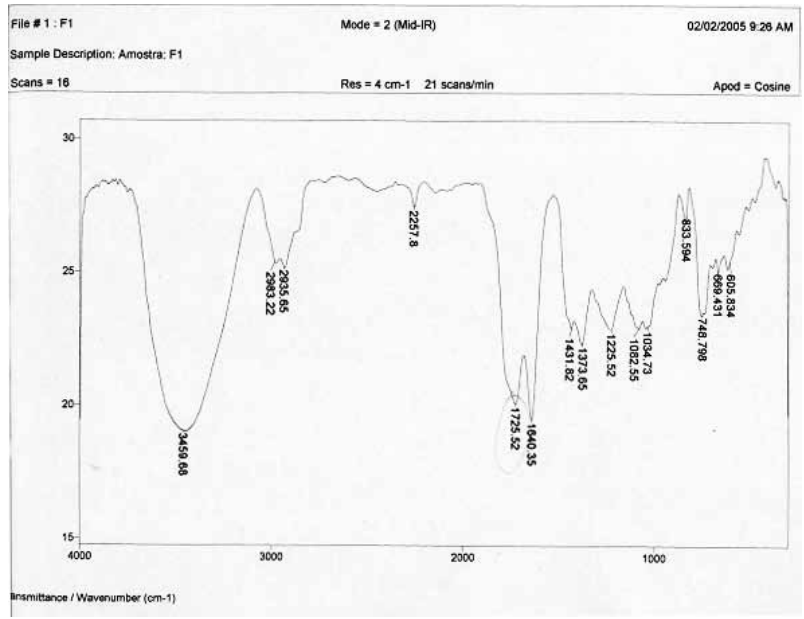

Figure 7. IR spectrum of DCM fraction.

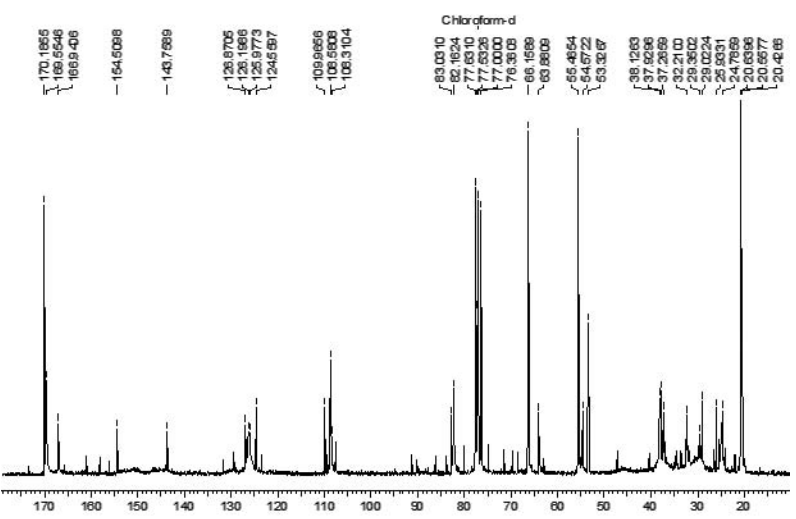

Figure 8. ${ }^{13} \mathrm{C}$ NMR spectrum of SF 2125 fraction. $\left(\mathrm{CDCl}_{3}, 75\right.$ $\mathrm{MHz}$. 
scorpioides has been studied in different biological tests and has shown cytotoxic effects in most of these. Previous studies show that dichloromethane and hexane fractions from the extract show fungicide and bactericide properties (Freire et al., 1996). Also, many Vernonia species are used as trypanocidals (Tchinda et al., 2002) and antihelmintics (Hordegen et al., 2003). We have now advanced our understanding of the antitumoral potential of $V$. scorpioides 2125 sub- fraction. Investigations into the mechanism of action for the tumor-reducing activity and also the compounds responsible for the cytotoxic activity are currently in progress.

\section{ACKNOWLEDGEMENTS}

The authors are grateful to Maria Corrêa for her technical support with the animals and Luciana Vizzoto (DQ-UFSCar) for recording NMR spectra.

\section{REFERENCES}

Biavatti M, Marensi V, Leite SN, Reis A 2007. Ethnopharmacognostic survey on botanical compendia for potential cosmeceutic species from Atlantic Forest. Rev Bras Farmacogn 17: 640-653.

Cabrera AL, Klein RM 1980. Compostas: 3. Tribo: Vernoniae. Fl Ilustr Catarin 354-355.

Christina AJM, Jose MA, Robert JH, Kothai R, Chidambaranathan N 2003. Effect of Indigofera aspalathoides against Dalton's ascitic. Fitoterapia 74: 280-283.

Dalazen P, Molon A, Biavatti MW, Kreuger MRO 2005. Effects of topical application of extract from Vernonia scorpioides on excisional wounds in mice. Rev Bras Farmacogn 15: 82-87.

Freire MFI, Abreu HS, Cruz LCH, Freire RB 1996. Inhibition of fungal growth by extracts of Vernonia scorpioides (Lam.) Pers. Microbiology 27: 1-6.

Hordegen P, Hertzberg H, Heilmann J, Langhans W, Maurer V 2003. The anthelmintic efficacy of five plant products against gastrointestinal trichostrongylids in artificially infected lambs. Rev Parasitol 117: 51-60.

Krishna Kumari GN, Masilamani S, Ganesh MR, Aravind S, Sridhar SR 2003. Zaluzanin D: a fungistatic sesquiterpene from Vernonia arborea. Fitoterapia 74 : 479-482.

Kuo YH, Kuo YJ, Yu AS, Wu MD, Ong CW, Yang Kuo LM, Huang JT, Chen CF, Li SY 2003. Two novel sesquiterpene lactones, cytotoxic vernolide-A and -B, from Vernonia cinerea. Chem Pharm Bull 51: 425426.

Leite SN, Palhano G, Almeida S, Biavatti MW 2002. Wound healing activity and systemic effects of Vernonia scorpioides extract in guinea pig. Fitoterapia 73: 496500.

Matsuzaki P, Akisue G, Oloris S, Górniak SL, Dagli MLZ 2003. Effect of Pfaffia paniculata (Brazilian ginseng) on the Ehrlich tumor in its ascitic form. Life Sci 74: 573-579.

Pagno T, Blind LZ, Biavatti MW, Kreuger MRO 2006. Cytotoxic activity of the dichloromethane fraction from Vernonia scorpioides (Lam.) Pers. (Asteraceae) against Ehrlich's tumor cells in mice. Braz J Med Biol Res 39: 1483-1491.

Tchinda AT, Tsopmo A, Tane P, Ayafor JF, Connolly JD, Sterner
O 2002. Vernoguinosterol and vernoguinoside, trypanocidal stigmastane derivatives from Vernonia guineensis (Asteraceae). Phytochemistry 59: 371-374. 